This is the final peer-reviewed accepted manuscript of:

Amicucci, Antonella; Barbieri, Elena; Sparvoli, Valentina; Gioacchini, Anna Maria;

Calcabrini, Cinzia; Palma, Francesco; Stocchi, Vilberto; Zambonelli, Alessandra

"Microbial and pigment profile of the reddish patch occurring within Tuber magnatum ascomata"

which has been published in final form in FUNGAL BIOLOGY 2018, vol. 122 (12), pp. 1134-1141

The final published version is available online at:

https://doi.org/10.1016/i.funbio.2018.07.007

(C) 2018 This manuscript version is made available under the Creative Commons AttributionNonCommercial-NoDerivs (CC BY-NC-ND) 4.0 International License

(http://creativecommons.org/licenses/by-nc-nd/4.0/) 


\title{
Microbial and pigment profile of the reddish patch occurring within Tuber magnatum ascomata
}

\author{
Antonella Amicucci a, b, *,, , Elena Barbieri ${ }^{\text {a, }{ }^{* *}, 1}$, Valentina Sparvoli a , \\ Anna Maria Gioacchini ${ }^{a}$, Cinzia Calcabrini ${ }^{a}$, Francesco Palma a , Vilberto Stocchi ${ }^{\text {a, }}{ }^{2}$, \\ Alessandra Zambonelli b, 2 \\ a Department of Biomolecular Sciences, University of Urbino Carlo Bo, 61029 Urbino, Italy \\ ${ }^{\mathrm{b}}$ Department of Agricultural and Food Sciences, University of Bologna, 40127 Bologna, Italy
}

\section{A R T I C L E I N F O}

\section{Article history:}

Received 19 January 2018

Received in revised form

19 July 2018

Accepted 23 July 2018

Available online $\mathrm{xxx}$

Corresponding Editor: Angel Medina

\section{Keywords:}

16S rRNA gene

Bacterial community

Carotenoid pigments

Red patch

White truffle

\begin{abstract}
A B S T R A C T
Tuber magnatum Pico, the delectable white truffle, is the most prized truffle species. In this study, we examined the reddish pigmentation that frequently occurs in T. magnatum ascomata for the presence of pigment-producing bacteria.

The inner part of the reddish-pigmented region of three $T$. magnatum ascomata collected in North-Central Italy was analysed. This reddish part was used to establish a bacterial culture collection and to extract the total genomic DNA in order to obtain a library of 16S rRNA genes representative of the bacterial community. The molecular approach revealed limited microbial diversity within the reddishpigmented regions compared to the wider range of bacterial species commonly found at the same maturation stage and season in T. magnatum ascomata. The pigmented regions showed a prevalence of specific bacterial species belonging to $\alpha$-, $\beta$ - and $\gamma$-Proteobacteria, Actinobacteria and Firmicutes. From the tandem mass spectrometry analysis of the extracted pigment, four compounds were identified: i) bixin, ii) $\beta$-carotene, iii) cis-1-glycosyl-apo-8'- lycopene and iv) the fucoxanthin. Carotenoid producing species such as Microbacterium and Chryseobacterium emerged as the most likely cause of the peculiar reddish pigment production. Indeed, our findings suggest that the peculiar reddish pigment might be produced by these bacterial species.
\end{abstract}

๑) 2018 British Mycological Society. Published by Elsevier Ltd. All rights reserved.

\section{Introduction}

Truffles are ectomycorrhizal ascomycetous fungi belonging to the genus Tuber order Pezizales (Bonito and Smith, 2016). Most of these fungi are of considerable interest as they produce edible fruiting bodies appreciated for their organoleptic properties and high commercial value. Of all the truffle species, Tuber magnatum

\footnotetext{
* Corresponding author. Department of Biomolecular Sciences, University of Urbino Carlo Bo, Via Saffi 2, 61029 Urbino, Italy. Fax: +39 0722305324

** Corresponding author. Department of Biomolecular Sciences, University of Urbino Carlo Bo, Via Maggetti 26, 61029 Urbino, Italy. Fax: + 390722303401.

E-mail addresses: antonella.amicucci@uniurb.it (A. Amicucci), elena.barbieri@ uniurb.it (E. Barbieri), valentina.sparvoli@gmail.com (V. Sparvoli), anna. gioacchini@uniurb.it (A.M. Gioacchini), cinzia.calcabrini@uniurb.it (C. Calcabrini), francesco.palma@uniurb.it (F. Palma), vilberto.stocchi@uniurb.it (V. Stocchi), alessandr.zambonelli@unibo.it (A. Zambonelli).

${ }^{1}$ These authors equally contributed to the paper.

${ }^{2}$ Equally contributing senior authors.
}

Pico, Italian white truffle, is the most valuable thanks to its unique pungent aroma and superb singular flavour (Hall et al., 2007; Gioacchini et al., 2005) as well as its limited geographical distribution (Hall et al., 2007; Riccioni et al., 2016).

The complex life cycle of truffles involves the following three fundamental stages: i) the "saprotrophic phase" during which the mycelium proliferates in the soil, ii) the "ectomycorrhizal phase" when the functional symbiotic structure is formed following the mutual recognition between the symbiotic fungus and the plant, and iii) the "reproductive phase" during which the fungus forms ascomata (Smith and Read, 2010).

Many biotic and abiotic factors can affect the life cycle of Tuber. Such factors include nutritional status, the cross-talk with the host plant before and after the formation of functional mycorrhiza, and the climatic and/or stress conditions (mycorrizosphere, pollutants in the soil, drought). Undoubtedly, the complexity of this ecosystem results in an inter- and intraspecific variability in the duration of the biological cycle that makes the cultivation of truffles, in 
particular T. magnatum, difficult (Amicucci et al. 2010, 2011; Leonardi et al., 2017; Riccioni et al., 2016).

Among the various biotic factors that influence the ontogeny of ectomycorrhizal fungi, soil microorganisms, such as bacteria and other fungi, play an important role (Frey-Klett et al., 1997; Aspray et al., 2006). As regards the bacterial community, some species, called "mycorrhization helper bacteria", promote the growth of the mycelium as well as ectomycorrhiza formation (Frey-Klett et al., 2007). It has also been speculated that the bacterial community may play a role in the development and maturation of the fruiting body (Bedini et al., 1999; Citterio et al., 2001; Sbrana et al., 2002).

Indded, the functional potentials of these bacteria within truffle ascoma seem to be related to several biological activities such as nitrogen fixation, cellulose/chitin degradation, and sulphur metabolism (Barbieri et al., 2010; Antony-Babu et al., 2014; Splivallo et al., 2014). In particular, nitrogen fixation function has been reported in T. magnatum by Bradyrhizobium spp. (Barbieri et al., 2010). Bacteroidetes and Actinomycetes have been described for their role in cellulose/chitin degradation, and their possible contribution to the release of the ascospores (Gazzanelli et al., 1999; Citterio et al., 2001). Moreover, $\alpha$ and $\beta$-Proteobacteria are thought to be involved in the release of sulphur volatile compounds such as thiophene derivatives, characteristic of Tuber borchii fruiting bodies (the "bianchetto" truffle), and other sulphur-containing volatiles that have a central role in the truffle aroma that attracts mammals and also contribute to the truffle aroma sensed by humans (Splivallo et al., 2014).

In previous studies (Barbieri et al. 2007, 2010) on T. magnatum ascoma, bacterial species belonging to four different phyla were characterized: $\alpha, \beta$ and $\gamma$-Proteobacteria (Sinorhizobium/Ensifer, Rhizobium, Mesorhizobium, Bradyrhizobium, Variovorax, Burkholderia, Pseudomonas fluorescens, Moraxellaceae, Xanthomonadaceae and Enterobacteriaceae), Bacteroidetes (Sphingobacteriaceae, Flexibacteriaceae e Flavobacteriaceae), Actinobacteria (Micrococcaceae, Microbacteriaceae, Propionibacteriaceae e Nocardiaceae) and Firmicutes (Staphylococcaceae, Listeriaceae, Bacillaceae $e$ Clostridiaceae).

T. magnatum ascomata usually have a smooth to suede-like surface, a colour that varies from pale yellowish brown to yellow ochra, olivaceous or greenish grey sometimes presenting black, rust-coloured or brownish spots. The gleba is criss-crossed with numerous, fine, clear veins, which are light hazel at maturity (Hall et al., 2007). T. magnatum ascomata sometimes exhibit anomalous bright red patches. These patches may be superficial or develop inside the gleba; but, they do not alter the aromatic proprieties or commercial value of truffles (Ceruti et al., 2003; Zambonelli and Iotti, 2005; http://www.italian-products.com/freshtruffles-info). Nevertheless, this particular coloration has always aroused the curiosity of truffle hunters who have come up with the most imaginative explanations for this chromatic alteration. From a scientific standpoint, it is reasonable to suppose that the alteration is caused by the microorganisms, fungi and/or bacteria, which populate the truffle ascoma (Pacioni and Leonardi, 2016). Indeed, it is well known that several yeasts, filamentous fungi and bacteria produce red pigments (Rao et al., 2017).

In this study, we examined the possible etiopathological role of bacteria in this chromatic abnormality. To this aim, the bacterial community in samples of T. magnatum with red patches were characterized to assess whether certain bacterial species may be responsible for this phenomenon. Experimentally, the truffle samples were analysed using a dual approach: (1) cultivation and direct 16S rRNA gene (rDNA) sequence retrieval to focus on the natural bacterial community associated with the reddish patch within T. magnatum ascomata, (2) mass spectrometry profile of the pigment extracted from the altered tissues.

\section{Material and methods}

\subsection{Biological materials}

Samples of glebal tissue were obtained by dissection with a sterile scalpel from the inner part of three different fresh $T$. magnatum ascomata (AN1, NCS4 and AA). Specimens were characterized by anomalous bright red patches.

\subsection{Culture media and isolation of culturable bacterial strain from T. magnatum ascocarps}

Bacterial species present in T. magnatum ascomata were isolated and cultured on Petri dishes containing Laked Blood Agar (LBA) (20 g/l) or Tryptone Soy Agar (TSA) (40 g/l) soils (Difco).

Five milliliters of saline solution $(0.9 \% \mathrm{NaCl})$ were added to $50 \mathrm{mg}$ of the inner part of the reddish ascoma, sampled with a sterile scalpel to limit external contamination during slicing. The sample was then homogenized using a sterile glass potter.

Serial dilutions of the homogenate in $0.9 \% \mathrm{NaCl}$ solution up to a dilution of $10^{-7}$ were prepared. Then, $100 \mu \mathrm{l}$ of each suspension was spread on TSA and LBA plates and incubated at $28^{\circ} \mathrm{C}$ for at least $48 \mathrm{~h}$. After incubation, the colonies that grew were harvested with a sterile loop and spread onto new LBA or TSA plates and incubated at room temperature for $48 \mathrm{~h}$. This procedure was repeated $2-3$ times to obtain pure bacterial isolates.

\subsection{Extraction of bacterial DNA from fruiting bodies of T. magnatum}

The bacterial DNA was extracted from T. magnatum ascomata, which ranged in weight from 10 to $200 \mathrm{mg}$, using the following protocol: three hundred microliters of lysis buffer (200 mM Tris$\mathrm{HCl} \mathrm{pH} 7.5,250 \mathrm{mM} \mathrm{NaCl}, 25 \mathrm{mM}$ EDTA, $0.5 \% \mathrm{SDS}$ ) was added to $150 \mathrm{mg}$ of carpophore, the sample was frozen with liquid nitrogen and homogenized with a sterile micropestle. After adding another $500 \mu \mathrm{l}$ of lysis buffer, the sample was mixed by vortexing for $10 \mathrm{~s}$ and then centrifuged for $10 \mathrm{~min}$ at $10000 \times \mathrm{g}$. One volume of isopropanol was added to the recovered supernatant, and the mixture was incubated at $-20{ }^{\circ} \mathrm{C}$ for $15-30 \mathrm{~min}$. The sample was then centrifuged at maximum speed for $15 \mathrm{~s}$. The supernatant was discarded, while the pellet was dried at room temperature and then resuspended in $200 \mu \mathrm{L}$ of sterile water. Finally, the sample was incubated at $70{ }^{\circ} \mathrm{C}$ for $15 \mathrm{~min}$ and centrifuged for $2 \mathrm{~min}$ at maximum speed. The supernatant was then recovered. The quality of the extracted DNA was assessed by electrophoresis on $1.2 \%$ agarose gel in TBE buffer (0.5X). The molecular ladder DNA/Hind III markers (125-23 $000 \mathrm{bp}$; Promega) were used. The visualization of the extraction product was obtained by staining the gel with a solution containing $100 \mathrm{ml}$ of TBE (0.5X), $2 \mathrm{ml} 0.5 \mathrm{M} \mathrm{NaCl}$ and $7 \mu \mathrm{l}$ GelRed (10.000X, Biotium), with image acquisition performed by GelDoc (BioRad).

\section{4. $16 S$ rDNA amplification by $P C R$}

The amplification of the 16S rDNA region both from ascomata DNA and from each isolated bacterial strain was performed using the following reaction conditions: $1 \mathrm{X}$ buffer, $3 \mathrm{mM} \mathrm{MgCl}_{2}, 200 \mu \mathrm{M}$ dNTPs, $1 \mu \mathrm{M}$ primers UP Forward (5'-AGAGTTTGATYMTGGC- $3^{\prime}$ ) and UP Reverse (5'-GYTACCTTGTTACGACTT-3') (Barbieri et al., 2007), $0.04 \mathrm{U} / \mu \mathrm{l}$ Taq DNA polymerase (Diatheva), $1 \mu \mathrm{l}$ extracted DNA and milliQ sterile water up to the final volume of $12.5 \mu \mathrm{l}$. The amplification of the bacterial isolates was performed by adding a colony taken with a sterile tip directly to the reaction mix without previous extraction as described in Barbieri et al. (2007). The thermocycler 
was set up as follows: initial denaturation at $94{ }^{\circ} \mathrm{C}$ for $10 \mathrm{~min}$ to ensure the lysis of bacterial cells, 30 cycles of denaturation at $94^{\circ} \mathrm{C}$ for $45 \mathrm{~s}$, annealing at $53{ }^{\circ} \mathrm{C}$ for $45 \mathrm{~s}$, elongation at $72{ }^{\circ} \mathrm{C}$ for $2 \mathrm{~min}$ and a final elongation at $72{ }^{\circ} \mathrm{C}$ for $7 \mathrm{~min}$. PCR products were analysed by electrophoresis as described above.

\section{5. $16 S$ rDNA library construction}

The 16S rDNA amplicons obtained from the bacterial DNA extracted from the fruiting bodies were cloned into the plasmid vector pGEM-T by pGEM ${ }^{\circledR}-\mathrm{T}$ Easy Kit (Promega) as recommended by the manufacturer. One $\mu \mathrm{l}$ of ligation product was added to a $50 \mu \mathrm{l}$ aliquot of $E$. coli XL1BLUE competent cells, and the mixture was incubated on ice for $1 \mathrm{~min}$. The mixture was then transferred to an electroporation cuvette, then treated with an electric shock $(1.8 \mathrm{KV})$, and immediately mixed with $1 \mathrm{ml}$ of LB broth. After incubation at $37{ }^{\circ} \mathrm{C}$ for $1 \mathrm{~h}$ while stirring, 200 and $800 \mu \mathrm{l}$ of the bacterial growth was spread on Petri dishes containing LB, ampicillin $(100 \mu \mathrm{g} / \mathrm{ml}), \mathrm{X}-\mathrm{Gal}(40 \mathrm{ug} / \mathrm{ml})$ and IPTG $(0.1 \mathrm{mM})$, and incubated at $37{ }^{\circ} \mathrm{C}$ for $16 \mathrm{~h}$. After incubation white colonies were selected for screening of the recombinant clones by PCR.

\subsection{Recombinant clone screening by colony PCR}

The screening of the recombinant clones was carried out by colony PCR. Each colony was suspended in $25 \mu \mathrm{l}$ of a reaction mix consisting of $1 \mathrm{X}$ buffer, $1.5 \mathrm{mM} \mathrm{MgCl} 2,200 \mu \mathrm{M}$ dNTPs, $0.4 \mu \mathrm{M}$ SP6 forward primer and $\mathrm{T} 7$ reverse primer, $1 \mathrm{U}$ Taq DNA polymerase (Diatheva), and milliQ sterile water up to the final volume. The cycling program was as follows: initial denaturation at $94{ }^{\circ} \mathrm{C}$ for $10 \mathrm{~min}$; 30 cycles of denaturation at $94{ }^{\circ} \mathrm{C}$ for $30 \mathrm{~s}$, annealing at $55{ }^{\circ} \mathrm{C}$ for $30 \mathrm{~s}$, and elongation at $72{ }^{\circ} \mathrm{C}$ for $2 \mathrm{~min}$ with a final elongation at $72{ }^{\circ} \mathrm{C}$ for $7 \mathrm{~min}$. The amplification product was analysed as described above using 100 bp DNA ladder (BioLabs) as a molecular marker.

\subsection{ARDRA analysis}

For each ascoma analysed, the amplification product of the colony PCR of 35 recombinant clones and the 16S rDNA PCR product of the isolated bacterial strains were digested with the restriction enzymes TaqI and Hinfl according to the manufacturer's instructions. The restriction fragments were analysed by electrophoresis on $1.8 \%$ agarose gel in 0.5X TBE buffer. Two-Log DNA Ladder (0.1-10.0 Kb; Biolabs) was used as a molecular marker, and the clones or isolated bacteria were clustered by comparison of the amplified rDNA restriction analysis (ARDRA) of the different operative taxonomic units (OTUs). A $97 \% 16 \mathrm{~S}$ rDNA sequence similarity threshold was used to delineate species with OTUs. One clone/ strain representative of each restriction pattern was chosen for $16 \mathrm{~S}$ rDNA sequencing and phylogenetic analyses. For each ARDRA profile detected, at least 3 clones, whose plasmids were purified and sequenced, were selected. For each of the last serial dilutions obtained from homogenized carpophores, between 30 and 40 isolated strains were purified and chosen for 16S rDNA ARDRA analysis and sequencing.

\subsection{Sequencing of $16 S$ rDNA of recombinant clones and isolated bacteria}

Each representative recombinant clone was inoculated in $5 \mathrm{ml}$ of LB broth and incubated at $37{ }^{\circ} \mathrm{C}$ overnight. The cells were recovered by centrifugation at $4000 \mathrm{rpm}$ for $10 \mathrm{~min}$ and used for plasmid DNA extraction using Plasmid Mini Kit (Qiagen) according to the manufacturer's instructions. For each representative bacterium, the 16S rDNA PCR product was purified from agarose gel using the QIAquick Gel Extraction Kit (Qiagen). The quality and concentration of the purified DNA was evaluated by NanoDrop ${ }^{\circledR}$ ND-1000 (Celbio), and the extract was sequenced at MWG Eurofin Genomics (Germany).

\subsection{Comparative analysis of the sequencing results}

The results obtained from the sequencing of the 16S rDNA of the bacterial isolates and recombinant clones were compared with homologous sequences available in the GenBank database of the National Center for Biotechnology Information (http://www.ncbi. nlm.nih.gov) using the BLASTN algorithm. For the identification of bacterial species, only the alignments with a percentage of similarity greater than or equal to $98 \%$ were taken into consideration. The sequences were deposited in GenBank (Culture Indipendent Clones: MH717840-MH717873; Culture Dependent Strains: MH722302-MH722308).

\subsection{Phylogenetic analysis}

The GenBank nucleotide sequences used for comparative analyses were grouped into taxonomic subdivisions and then aligned using the ClustalW package (TreeBASE N. ID 23149). For the construction of the phylogenetic trees, the neighbor-joining method (NJ), the Kimura 2 parametric model and the MEGA version 4.046 were used (Tamura et al., 2007).

\subsection{Pigment extraction and mass spectrometer analyses}

Fifteen milligrams of reddish ascoma were frozen in liquid nitrogen and homogenised with a sterile micro-pestle. After performing two washes with $100 \mu \mathrm{l}$ of hexane and removing it with absorbent paper, $150 \mu \mathrm{l}$ of water and $150 \mu \mathrm{l}$ of $\mathrm{n}$ - butanol were added, then mixed well by vortexing (Tsuchida et al., 2010). The sample was then centrifuged for $1 \mathrm{~min}$ at maximum speed, the butanol phase and the aqueous phase were recovered separately and transferred into a clean micro-tube. A second extraction with an additional $200 \mu \mathrm{l}$ of n-butanol was performed. The butanol phase was recovered, pooled with the previous one, and dried. Finally, the extract obtained was resuspended in $15 \mu \mathrm{l}$ of methanol and stored at $-80^{\circ} \mathrm{C}$.

The extracts were solubilized in $50 \mu \mathrm{l}$ of methanol (Methanol LC-MS Chromasolv ${ }^{\circledR}$ Fluka) and infused by a quadrupole hybrid mass spectrometer (QTOF Micro, Micromass MS Technologies, Manchester, UK) with electrospray source (ESI). A voltage of $3.300 \mathrm{~V}$ and $40 \mathrm{~V}$ was applied to the capillary and to the cone respectively. The analyses were performed in positive and negative ion mode, and the most interesting ions were analysed by MS/MS experiments to obtain fragmentation spectra.

\section{Results and discussion}

This is the first study that characterizes the profile of carotenoids and identifies the main components associated with the red patch, which frequently occurs in T. magnatum ascomata suggesting a possible role of bacteria in this chromatic abnormality.

The presence of bacterial species in the gleba of truffles has been studied for decades (Frey-Klett et al., 1997; Aspray et al., 2006). It is likely that they enter the truffle in the early stages of the development of the ascoma. Indeed, it has been reported (Callot, 1999) that in the initial stages of ascoma formation, sterile veins connected with the outside environment are formed, and numerous bacteria can settle. Subsequently, the ascoma becomes compact and the bacteria remain inside, creating a specific niche. 
The molecular identification of the bacterial communities associated with the distinctive bright red patches occurring in fruiting bodies of $T$. magnatum was made using both culturedependent and -independent approaches.

In the culture independent approach, ARDRA analysis of 35 clones allowed us to identify 12 restriction profiles for the sample AN1, 17 for NCS4 and 12 for AA.

Table 1 shows the OTUs and the coverage obtained by 16S rRNA (rDNA) sequence analysis from both bacterial isolated strains and clones. Although the $97 \% 16 \mathrm{~S}$ rDNA sequence similarity threshold used to delineate species with OTUs is only a rough approximation, in this study, sequence similarity for defining OTUs helped to define the degree of microbial diversity of the biota found in the red patches occurring in T. magnatum ascomata. We were then able to compare these results at least as recorded species number with findings from previous studies such as Barbieri et al., 2007. In the red patches of T. magnatum ascomata, OTUs ranged from 2 to 3 and from 4 to 7 for strains and clones respectively; while in Barbieri et al., (2007), a higher recorded species number was observed, specifically up to 6 different OTUs for strains and up to 10 OTUs for clones, respectively.

Bioinformatics analysis of the sequences obtained with the BLASTN algorithm allowed the identification of the bacterial species as reported in Table 2.

The sequence analysis allowed us to construct a phylogenetic tree and therefore place the identified species in their taxonomic contexts (Fig. 1).

The results show that in the reddish T. magnatum gleba, the microbial community consists of bacterial species previously found within white truffles without reddish patches (Barbieri et al., 2007).

However, a significant decrease in recorded species number was found in the pigmented ascomata with a prevalence of specific bacterial species belonging to $\alpha$-, $\beta$ - and $\gamma$-Proteobacteria, Actinobacteria and Firmicutes.

Of particular interest are the bacterial species able to produce pigments: (1) among $\alpha$-, $\beta$ - and $\gamma$-Proteobacteria: Rhizobium sp., Bradyrhizobium sp., Variovorax spp., Pseudomonas sp., (2) among Bacteroidetes: Chryseobacterium sp., (3) among Actinobacteria: Microbacterium sp. and Arthrobacter sp., and finally (4) among the Firmicutes: Bacillus sp (Trutko et al., 2005; Paret et al., 2010; Kamyama et al., 1995; Kobayashi et al., 1995).

The specific role of these bacteria in truffles is not known. Previous studies have only reported the ability of Rhizobium spp. and Bradyrhizobium spp. to fix nitrogen (Barbieri et al., 2010).

In order to restrict the range of bacterial species thought to be responsible for the chromatic alteration, biochemical analyses were carried out to characterize the pigment. The analysis performed by mass spectrometer showed the presence of pigments belonging to the category of beta-carotenoids. Carotenoids are common pigments produced by a wide variety of bacteria, algae, fungi, and plants. In the late 1950s it was shown that the carotenes from symbiotic bacteria can protect their host organisms against lethal photodynamic reactions and that these pigments are produced in response to various stimuli (Stanier and Cohen-Bazire, 1957;
Cohen-Bazire and Stanier, 1958). We assumed that in the reddish patches, carotenoids might derive from a yet to be defined, particular environmental condition, in which specific microorganisms could find the favourable niche to synthesize them.

The electrospray tandem mass spectrometry analysis of the butanol extract, conducted by direct infusion and performed on homogenates of pigmented portions of $T$. magnatum ascomata, allowed us to obtain information on the pigment responsible for the characteristic colour observed. The full-scan mass spectrum of the sample (range $200-1200 \mathrm{~m} / \mathrm{z}$ ) is very complex. The ions of interest were studied by collision experiments, which allowed us to fragment the ions and to study their structure. From the data obtained, we were able to identify and characterize four different carotenoids in the AN1 sample: $\beta$-carotene, cis-1-glycosyl-apo- $8^{\prime}$ lycopene, fucoxanthin and bixin (Fig. 2).

Since the OTUs occurring in this limited area are few, we assume that it can be colonised by carotenoids producing bacteria in response to various environmental features. Of the detected species, the chromatic alteration may be triggered by the Microbacterium spp. belonging to the group of Actinobacteria, which are gram-positive and filamentous with a mycelial-type growth (Ventura et al., 2007), and the Chryseobacterium spp., belonging to the family of Flavobacteria, which are aerobic gram-negative commensal bacteria and opportunistic pathogens. In fact, it is reported in the literature that several strains belonging to the Microbacteriaceae family produce yellow, orange and red pigments, with an absorption spectrum typical of that of carotenoids. Furthermore, it has been reported that some strains can produce reddish pigmentation on the surface of certain types of cheese (Brennan et al., 2001). On the other hand, regarding the Chryseobacterium, strains belonging to this species are frost tolerant, proteolytic, and responsible for various defects in different food matrices (González et al., 2000; Hugo et al., 1999, 2003; Chaudhari et al., 2009). In particular, strains able to produce yellow pigments in the category of carotenoids have been isolated in whole milk (Hantsis-Zacharov and Halpern, 2007). In the literature, among the carotenoids found in T. magnatum red patches, Bixin, $\beta$-carotene and cis-1-glycosyl-apo-8'-lycopene have been associated with Microbacterium spp. (Ojha et al., 2018). This species appears to be the most probable candidate for production, at least in part, of carotenoids in the truffle.

Another bacterial species detected in the reddish specimens belongs to the species Janthinobacterium spp., $\beta$-Proteobacteria, which has not been previously detected in T. magnatum ascomata.

It has been reported that some Janthinobacterium strains can exhibit both purple- and red-pigmentations, depending on temperature and soil composition (Schloss et al., 2010; Ambrožič et al., 2013). This pigmentation could protect against photobiological damage (Caldas et al., 1978), and shows antibacterial activity (Mojib et al., 2010). Nevertheless, the pigment produced by Janthinobacterium species is a violacein-like purple violet pigment (PVP) (Mojib et al., 2013), and not a carotenoid. Hence, the Janthinobacterium spp. is probably not the etiologic cause of the reddish patch on T. magnatum ascomata.

Table 1

List of T. magnatum Pico ascomata used in this study and the corresponding numbers of isolates and clones in the culture collection and in the clone library respectively.

\begin{tabular}{|c|c|c|c|c|c|c|}
\hline T. magnatum ascoma & $\mathrm{CFU} \mathrm{g}^{-1}$ & No. of isolates & OTUs $^{\mathrm{b}}$ & No. of clones & OTUs $^{a}$ & Coverage $^{\mathrm{b}}$ \\
\hline NCS4 & $2.1 \pm 0.27 \times 10^{6}$ & 33 & 3 & 52 & 6 & $81 \%$ \\
\hline AN1 & $1.8 \pm 0.86 \times 10^{6}$ & 32 & 3 & 40 & 7 & $83 \%$ \\
\hline $\mathrm{AA}$ & $9.7 \pm 0.47 \times 10^{5}$ & 29 & 4 & 46 & 4 & $80 \%$ \\
\hline
\end{tabular}

a OTUs, operational taxonomic units.

b Coverage was calculated according to the formula $C=1-\left(n 1 \times N^{-1}\right) \times 100 \%, n 1=$ No. of OTUs consisting of only one sequence, $N=$ No. of all sequences in the $16 \mathrm{~S}$ rDNA clone library. 
Table 2

Identification of the bacterial species by bioinformatic analysis of the 16 rRNA sequences using BLASTN algorithm.

\begin{tabular}{|c|c|c|c|c|c|c|c|c|c|}
\hline \multirow[t]{2}{*}{ Phylogenetic affiliation } & \multirow[t]{2}{*}{ OTUs } & \multicolumn{3}{|c|}{ Bacterium or clone with highest 16 rRNA sequence similarity } & \multirow{2}{*}{$\begin{array}{l}\text { T. magnatum } \\
\text { ascocarps }\end{array}$} & \multirow[t]{2}{*}{ Sequenced clones } & \multirow[t]{2}{*}{ N. of clones } & \multirow[t]{2}{*}{ Sequenced strains } & \multirow[t]{2}{*}{ N. of strains } \\
\hline & & Name or designation & $\begin{array}{l}\text { Similarity \% } \\
(\mathrm{nt} / \mathrm{nt})^{\mathrm{a}}\end{array}$ & GenBank Accession N. & & & & & \\
\hline \multirow[t]{6}{*}{ Alpha proteobacteria } & 1 & Sinorhizobium sp. S1-T-10 & $97-98$ & AY505133.1 & NCS4 & $\begin{array}{l}\text { NCS4-Cl-Q, NCS4-CI-F, } \\
\text { NCS4-CI-C, NCS4-CI-R }\end{array}$ & 15 & & \\
\hline & 1 & Rhizobium leguminosarum & 99 & GQ863505.1 & NCS4 & NCS4-CI-E & 3 & & \\
\hline & 2 & Bradyrhizobium sp. КН20B & 98 & AB551574.1 & NCS4 & NCS4-CI-B & 9 & & \\
\hline & 3 & Ochrobactrum sp. LMG 20564 16S & 98 & AF452128.1 & AN1 & AN1-CI-B & 5 & & \\
\hline & 3 & Methylobacterium sp. ED325 & 99 & GQ342537.1 & NCS4 & NCS4-CI-L & 5 & & \\
\hline & 3 & Phyllobacterium sp. DSM 17640 & 98 & DQ431466.1 & AN1 & AN1-CI-E & 3 & & \\
\hline \multirow[t]{7}{*}{ Beta proteobacteria } & 4 & Variovorax sp. TM10_10 & 97 & DQ279348.1 & NCS4 & NCS4-CI-G & 4 & & \\
\hline & 5 & Alcaligenes xylosoxidans & 97 & AJ491845.1 & AN1 & AN1-Cl-F & 4 & & \\
\hline & 5 & $\begin{array}{l}\text { Alcaligenes xylosoxidans } 16 \mathrm{~S} \text { rRNA gene, } \\
\text { strain F }\end{array}$ & 98 & AJ491845.1 & AA & $\mathrm{AA}-\mathrm{Cl}-\mathrm{F}$ & 4 & & \\
\hline & 5 & Alcaligenes sp. MG07 & 98 & HQ670710.1 & AA & AA-CI-G & 4 & & \\
\hline & 4 & Rhodoferax sp. Asd M2A1 16S & 97 & FM955857.1 & AN1 & AN1-CI-N & 4 & & \\
\hline & 6 & Janthinobacterium sp. HC7-17 & 98 & JF313035.1 & $\mathrm{AA}$ & AA-CI-N & 4 & & \\
\hline & 4 & Comamonas sp. TK41 & 98 & AJ550282.1 & AA & AA-CI-D & 2 & & \\
\hline \multirow[t]{9}{*}{ Gamma proteobacteria } & 6 & Pseudomonas putida & 99 & AM921634.1 & AN1 & AN1-CI-C & 7 & & \\
\hline & 6 & Pseudomonas sp. 01WB04.1-96 & 98 & FM161545.1 & AN1 & AN1-CI-D & 5 & & \\
\hline & 6 & Pseudomonas sp. An1 & 98 & AJ551142.1 & AN1 & AN1-CI-I & 5 & & \\
\hline & 6 & Pseudomonas sp. TM7_1 & 98 & DQ279324.1 & AN1 - AA & AA-Cl-H & 8 & AN1-CD-C & 18 \\
\hline & 6 & Pseudomonas lini strain DLE411J & 97 & NR_029042.1 & AA & AA-CI-A & 4 & & \\
\hline & 6 & Pseudomonas migulae strain CIP 105470 & 98 & NR_024927.1 & $\mathrm{AA}$ & AA-CI-C & 5 & & \\
\hline & 7 & Pseudomonas fluorescens strain F113 & 98 & AJ278814.1 & AA & AA-CI-E & 7 & & \\
\hline & 6 & Pseudomonas sp. TM14_2 & 97-99 & DQ279319.1 & AA & AA-CI-I, AA-CI-L & 6 & & \\
\hline & 9 & Stenotrophomonas humi strain R-32729 & 99 & NR_042568.1 & $\mathrm{AA}$ & AA-CI-M & 4 & & \\
\hline \multirow[t]{3}{*}{ Bacteroidetes } & 10 & Chryseobacterium sp. R-36555 & 98 & FR682717.1 & AN1 & AN1-CI-A & 3 & & \\
\hline & & Chryseobacterium sp. CI10 & 98 & DQ530078.1 & AN1 & AN1-Cl-H & 4 & & \\
\hline & & Chryseobacterium sp. CI09 & 97 & DQ530076.1 & AN1 & AN1-CI-L & 4 & & \\
\hline \multirow[t]{8}{*}{ Firmicutes } & 11 & Brochothrix thermosphacta & 98 & AY543027.1 & AN1 & AN1-CI-G & 6 & & \\
\hline & & Brochothrix sp. NJ-25 & 98 & AM409367.1 & AN1 & AN1-CI-M & 4 & & \\
\hline & & Brochothrix thermosphacta & 97 & JF756334.1 & AN1 & & & AN1-CD-A & 14 \\
\hline & & Brochothrix sp. E & 98 & KC618437.1 & AA & & & AA-CD-C & 9 \\
\hline & & Sporosarcina sp. B7-24 & 98 & KJ485702.1 & $\mathrm{AA}$ & & & AA-CD-B & 10 \\
\hline & 12 & Bacillus sp. $\mathrm{CdH}-3$ & 97 & EU190454.1 & NCS4 & & & NCS4-CD-D & 13 \\
\hline & & Bacillus sp. LKS-4 & 98 & JF502778.1 & NCS4 & & & NCS4-CD-E & 9 \\
\hline & 13 & Paenibacillus sp. MWE-A38 & 98 & JF722661.1 & NCS4 & & & NCS4-CD-A & 11 \\
\hline \multirow[t]{7}{*}{ Actinobacteria } & 14 & Microbacterium sp. T105 & 97 & FJ719325.1 & NCS4 & NCS4-CI-A & 4 & & \\
\hline & & Microbacterium sp. TV67May & 97 & KJ482888.1 & $\mathrm{AA}$ & & & AA-CD-E & 6 \\
\hline & & Microbacterium sp. WPCB194 & 98 & FJ006929.1 & NCS4 & NCS4-CI-M & 3 & & \\
\hline & 15 & Microlunatus panaciterrae & 98 & AB271051.1 & NCS4 & NCS4-CI-D & 3 & & \\
\hline & 16 & Arthrobacter sp. An32 & 98 & AJ551170.1 & NCS4 & NCS4-CI-N & 4 & & \\
\hline & & Arthrobacter sp. An12 & 97 & AJ551151.1 & AA & & & AA-CD-D & 4 \\
\hline & & Uncultured bacterium clone РВXВ4 & 97 & GU569130.1 & $\mathrm{AA}$ & AA-Cl-B & 1 & & \\
\hline
\end{tabular}




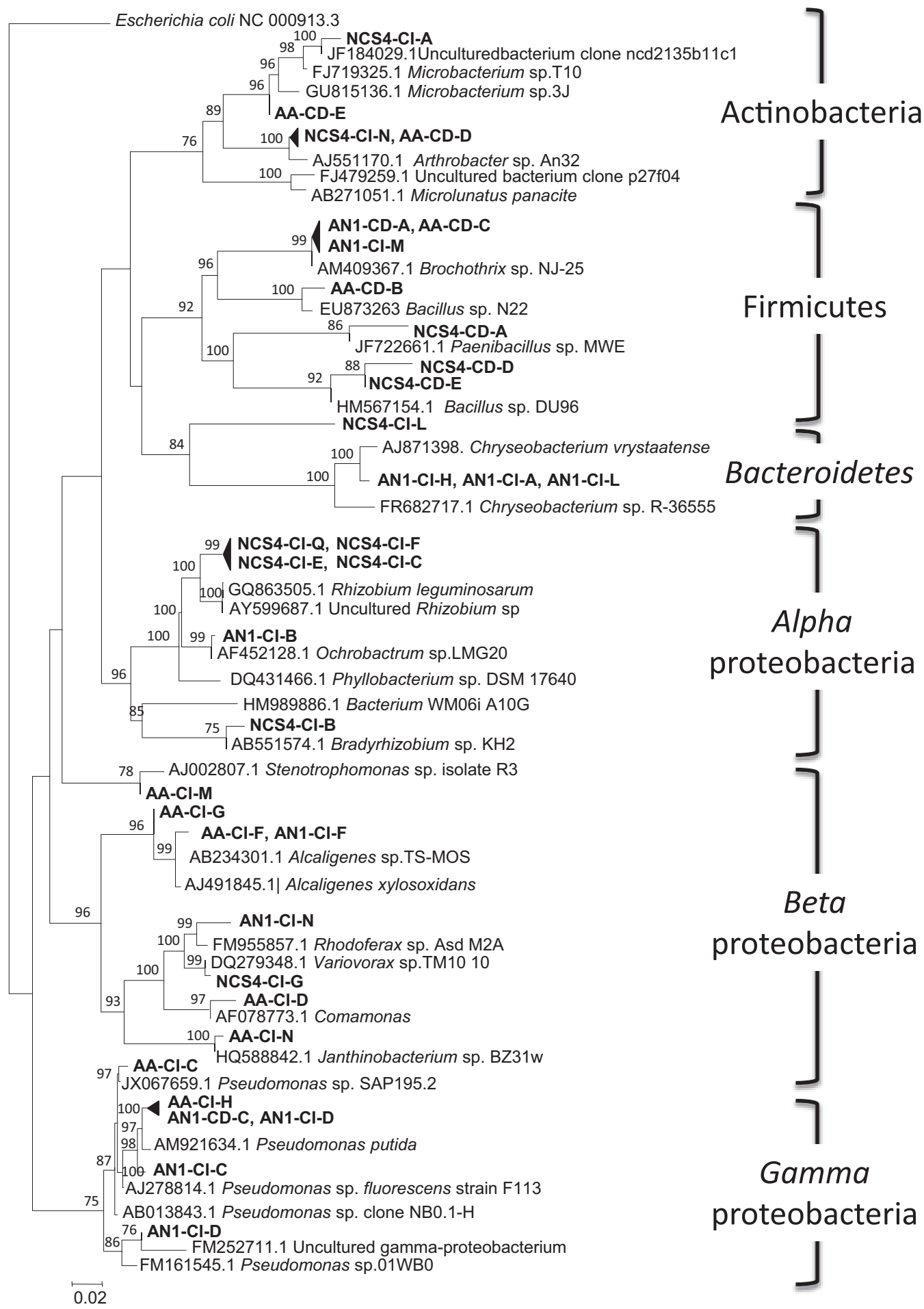

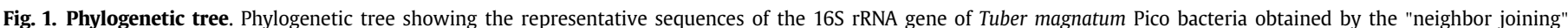

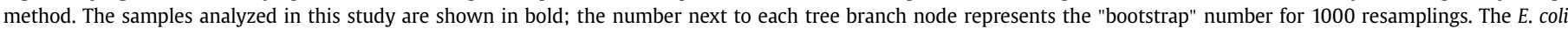
sequence is included as an outgroup.

Although it is reported that Microbacterium spp. can produce that those pigments (Ojha et al., 2018) among our isolates, none of them showed pigments in the culture conditions.

The condition of the hypogeous habitat and the maturation process of the truffle are influenced by continuous stresses such as temperature, humidity, etc. that may or may not favour the onset of bacterial colonization. Bacterial colonies that do establish themselves remain in the truffle and in favourable conditions, they release secondary products such as carotenoid pigments. These metabolites have specific predominantly antioxidant and antibacterial functional characteristics. They do not seem to alter the aromatic characteristics of the truffle's gleba matrix. The reduced number of OTUs in the red patch under study compared to the healthy gleba points to possible selective microbial activity. This selectivity could be of a specific chemoattractant type, only attracting some species due to nutritional/chemoattractive or 
B

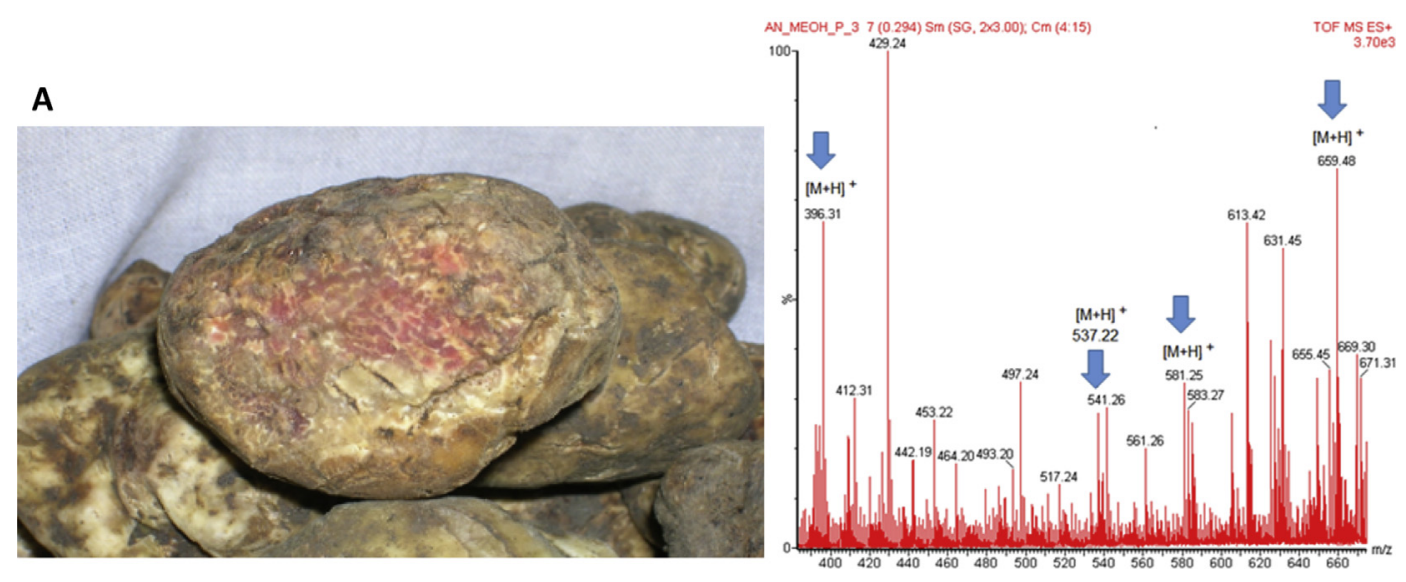

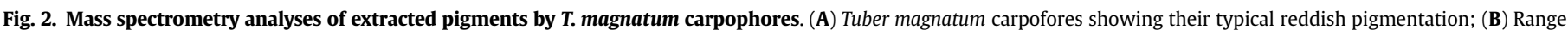

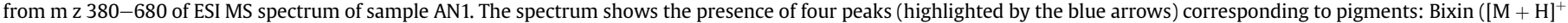

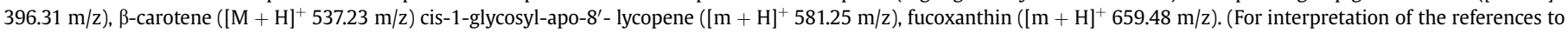
color/colour in this figure legend, the reader is referred to the Web version of this article.)

selective antimicrobial purposes; hence, only some species survive in the presence of carotenoids.

The differences in species composition within the red patches and the different truffle samples could depend on several factors. Indeed, bacterial communities of truffle ascocarps vary greatly in composition and richness during the maturation of the fruiting body and they also differ considerably from those from the bulk soil. Deveau and collegues 2016 observed seasonal truffleassociated bacterial community composition changes. Our results are consistent with recent findings from the same experimental site at the same period showing that a continuous supply of carbohydrates and nitrogen flows from ectomycorrhizae to the fruiting bodies during the maturation of the ascocarps. We propose that this creates a stable niche in the ectomycorrhizosphere, even if the phenology of the tree changes.

In conclusion, thanks to the combination of biomolecular approaches used in this study it was possible, for the first time, to characterize the bacterial and pigment profile of the reddish patch occurring within T. magnatum ascomata. The patch showed limited biodiversity, with a prevalence of Microbacterium and Chryseobacterium. Although we cannot exclude the possible role of yeasts and/or filamentous fungi, which populate T. magnatum ascomata (Buzzini et al., 2005, Pacioni et al., 2007), in this chromatic alteration, the Microbacterium and Chryseobacterium bacterial species appear to be the most likely etio-candidate.

To date there are no controlled laboratory systems for the production of valuable white truffles in which this peculiar and naturally occurring phenomenon can be reproduced. Truffle-associated bacteria cannot not be easily cultured in lab conditions; the bacteria that can be isolated culture media in the Petri dishes are only a small fraction of the total microbial diversity that occur in truffles (Barbieri et al., 2007). The cause-effect relationship that binds a specific microorganism to a particular host phenotype has not yet established. This study lays the bases for future research aiming to isolate carotenoid-producing bacteria and gain insight into specific pigment and allelochemical production.

\section{References}

Ambrožič, A.J. Žgur, B.D., Kostanjšek, R., Avguštin, G., 2013. Isolation and charac terization of a novel violacein-like pigment producing psychrotrophic bacterial species Janthinobacterium svalbardensis sp. nov. Antonie Van Leeuwenhoek 103 763-769.
Amicucci, A., Balestrini, R, Kohler, A., Barbieri, E, Saltarelli, R, Faccio, A Roberson, R.W., Bonfante, P., Stocchi, V., 2011. Hyphal and cytoskeleton polarization in Tuber melanosporum: a genomic and cellular analysis. Fungal Genet. Biol. 48, 561-572.

Amicucci, A., Zambonelli, A., Iotti, M., Polidori, E., Menotta, M., Saltarelli, R., Potenza, L., Stocchi, V., 2010. Morphological and molecular modifications induced by different carbohydrate sources in Tuber borchii. J. Mol. Microbiol. Biotechnol. 18, 120-128.

Antony-Babu, S., Deveau, A., Van Nostrand, J.D., Zhou, J., Le Tacon, F., Robin, C., FreyKlett, P., Uroz, S., 2014. Black truffle-associated bacterial communities during the development and maturation of Tuber melanosporum ascocarps and putative functional roles. Environ. Microbiol. 16, 2831-2847.

Aspray, T.J., Frey-Klett, P., Jones, J.E., Whipps, J.M., Garbaye, J., Bending, G.D., 2006. Mycorrhization helper bacteria: a case of specificity for altering ectomycorrhiza architecture but not ectomycorrhiza formation. Mycorrhiza 16, 533-541.

Barbieri, E., Guidi, C., Bertaux, J., Frey-Klett, P., Saltarelli, R., Zambonelli, A., Stocchi, V., 2007. Occurrence and diversity of bacterial communities in Tuber magnatum during truffle maturation. Environ. Microbiol. 9, 2234-2246.

Barbieri, E., Ceccaroli, P., Saltarelli, R., Guidi, C., Potenza, L., Basaglia, M., Fontana, F., Baldan, E., Casella, S., Ryahi, O., Zambonelli, A., Stocchi, V., 2010. New evidence for nitrogen fixation within the Italian white truffle Tuber magnatum. Fungal Biol. 114 (11-12), 936-942.

Bedini, S., Bagnoli, G., Sbrana, C., Leporini, C., Tola, E., Dunne, C., Filippi, C., D'Andre, F., O'Gara, F., Nuti, M.P. 1999. Pseudomonads isolated from within fruit bodies of Tuber borchii are capable of producing biological control or phytostimulatory compounds in pure culture. Symbiosis 26, 223-236.

Bonito, G.M. Smith, M.E. 2016. General systematic position of the truffles: evolutionary theories. In: Zambonelli, A., Iotti, M., Murat, C. (Eds.), True Truffle (Tuber spp.) in the World. Soil Biology, vol. 47. Springer, pp. 3-18.

Brennan, N.M., Brown, R., Goodfellow, M., Ward, A.C., Beresford, T.P., Vancanneyt, M., Cogan, T.M., Fox, P.F., 2001. Microbacterium gubbeenense sp. nov., from the surface of a smear-ripened cheese. Int. J. Syst. Evol. Microbiol. 51, 1969-1976.

Buzzini, P., Gasparetti, C., Turchetti, B., Cramarossa, M.R., Vaughan-Martini, A. Martini, A., Pagnoni, U.M., Forti, L., 2005. Production of volatile organic compounds (VOCs) by yeasts isolated from the ascocarps of black (Tuber melanosporum Vitt.) and white (Tuber magnatum Pico) truffles. Arch. Microbiol. 184, 187-193.

Caldas, L.R., Leitão, A.A.C., Santos, S.M., Tyrrell, R.M., 1978. Preliminary experiments on the photobiological properties of violacein. In: Tyrrell, R.M. (Ed.), Proceedings of the International Symposium on Current Topics in Radiology and Photobiology. Academia Brasileira de Ciências, Rio de Janeiro, pp. $121-126$.

Callot, G., 1999. La truffe la terre la vie. Institut National de la Recherche Agronomique-France, Paris, p. 210.

Chaudhari, P.N., Wani, K.S., Chaudhari, B.L., Chincholkar, S.B., 2009. Characteristics of sulfobacin A from a soil isolate Chryseobacterium gleum. Appl. Biochem. Biotechnol. 158, 231-241.

Ceruti, A., Fontana, A., Nosenzo, C., 2003. Le specie europee del genere Tuber. Una revisione storica. Monografie XXXVII. Museo Regionale di Scienze Naturali, Torino.

Citterio, B., Malatesta, M., Battistelli, S., Marcheggiani, F., Baffone, W., Saltarelli, R. Stocchi, V., Gazzanelli, G., 2001. Possible involvement of Pseudomonas fluorescens and Bacillaceae in structural modifications of Tuber borchii fruit bodies. Can. J. Microbiol. 47, 264-268. 
Cohen-Bazire, G., Stanier, R.Y., 1958. Specific inhibition of carotenoid synthesis in a photosynthetic bacterium and its physiological consequences. Nature 181, 250-252.

Deveau, A., Antony-Babu, S., Le Tacon, F., Robin, C., Frey-Klett, P., Uroz, S., 2016. Temporal changes of bacterial communities in the Tuber melanosporum ectomycorrhizosphere during ascocarp development. Mycorrhiza 26, 389-399.

Frey-Klett, P., Garbaye, J., Tarkka, M., 2007. The mycorrhiza helper bacteria revisited. New Phytol. 176, 22-36.

Frey-Klett, P. Pierrat, J.C., Garbaye, J., 1997. Location and survival of mycorrhiza helper Pseudomonas fluorescens during establishment of ectomycorrhizal symbiosis between Laccaria bicolor and Douglas Fir. Appl. Environ. Microbiol. 63, 139-144.

Gazzanelli, G., Malatesta, M., Pianetti, A., Baffone, W., Stocchi, V., Citterio, B., 1999. Bacteria associated to fruit bodies of the ecto-mycorrhizal fungus Tuber borchii Vittad. Symbiosis 26, 211-219.

Gioacchini, A.M. Menotta, M. Bertini, L, Rossi, I, Zeppa, S., Zambonelli, A. Piccoli, G., Stocchi, V., 2005. Solid-phase micro extraction gas chromatography/ mass spectrometry: a new method for species identification of truffles. Rapid Commun. Mass Spectrom. 19, 2365-2370.

González, C.J., Santos, J.A., Garcia-Lopez, M.L., Otero, A., 2000. Psychrobacters and related bacteria in freshwater fish. J. Food Protect. 63, 315-321.

Hall, I.R., Brown, G., Zambonelli, A., 2007. Taming the Truffle. The History, Lore, and Science of the Ultimate Mushroom. Timber Press, Portland, Oregon.

Hantsis-Zacharov, E., Halpern, M., 2007. Chryseobacterium haifense sp. nov., a psychrotolerant bacterium isolated from raw milk. Int. J. Syst. Evol. Microbiol. 57, 2344-2348.

Hugo, C.J., Jooste, P.J., Segers, P., Vancanneyt, M., Kersters, K., 1999. A polyphasic taxonomic study of Chryseobacterium strains isolated from dairy sources. Syst. Appl. Microbiol. 22, 586-595.

Hugo, C.J., Segers, P., Hoste, B., Vancanneyt, M., Kersters, K., 2003. Chryseobacterium joostei sp. nov., isolated from the dairy environment. Int. J. Syst. Evol. Microbiol. 53, $771-777$.

Kamyama, T., Umino, T., Sawairi, S., 1995. Sulfobacins A and B, novel von Willebrand factor receptor antagonists. I. Production, isolation, characterization and biological activities. Antibiotics 48, 924.

Kobayashi, J., Mikami, S., Shigemori, H., Toshifumi, T., Yasutsugu, S., Shunji, I., Shonen, Y., 1995. Flavocristamides A and B, new DNA polymerase a inhibitors from a marine bacterium Flavobacterium sp. Tetrahedron 51, 10487-10490.

Leonardi, P., Iotti, M., Donati Zeppa, S., Lancellotti, E., Amicucci, A., Zambonelli, A., 2017. Morphological and functional changes in mycelium and mycorrhizas of Tuber borchii due to heat stress. Fungal Ecol. 29, 20-29.

Mojib, N., Farhoomand, A., Andersen, D.T., Bej, A.K., 2013. UV and cold tolerance of a pigment-producing Antarctic Janthinobacterium sp. Ant5-2. Extremophiles 17, 367.

Mojib, N., Philpott, R., Huang, J.P., et al., 2010. Antimycobacterial activity in vitro of pigments isolated from Antarctic bacteria. Antonie van Leeuwenhoek 98, 531.
Ojha, S., Kapoor, S., Mishra, S., 2018. Carotenoid production by a novel isolate of Microbacterium paraoxydans. Indian J. Microbiol. 58, 118-122.

Pacioni, G., Leonardi, M., 2016. Truffle inhabiting fungi. In: Iotti, M., Murat, C., Zambonelli, A. (Eds.), True Truffle (Tuber spp.) in the World, Soil Ecology, Systematics and Biochemistry. Springer-Verlag, Berlin Heidelberg, pp. 283-299.

Pacioni, G., Leonardi, M., Aimola, P., Ragnelli, A.M., Rubini, A., Paolocci, F., 2007. Isolation and characterization of some mycelia inhabiting Tuber ascomata. Mycol. Res. 111, 1450-1460.

Paret, M.L., Sharma, S.K., Green, L.M., Alvarez, A.M., 2010. Biochemical characterization of Gram-positive and Gram-negative plant-associated bacteria with micro-Raman spectroscopy. Appl. Spectrosc. 64, 433-441.

Rao, M.P.N., Xiao, M., Li, W.J., 2017. Fungal and bacterial pigments: secondary metabolites with wide applications. Front. Microbiol. 8, 1-13.

Riccioni, C., Rubini, A., Belfiori, B., Gregori, G., Paolocci, F., 2016. Tuber magnatum: the special one. What makes it so different from the other Tuber spp.?. In: Zambonelli, A., Iotti, M., Murat, C. (Eds.), True Truffle (Tuber spp.) in the World. Soil Biology, vol. 47. Springer, pp. 87-103.

Sbrana, C., Agnolucci, M., Bedini, S., Lepera, A., Toffanin, A., Giovannetti, M. Nuti, M.P., 2002. Diversity of culturable bacterial populations associated to Tuber borchii ectomycorrhizas and their activity on T. borchii mycelial growth. FEMS Microbiol. Lett. 211, 195-201.

Schloss, P.D., Allen, H.K., Klimowicz, A.K., Mlot, C., Gross, J.A., Savengsuksa, S, McEllin, J., Clardy, J., Ruess, R.W., Handelsman, J., 2010. Psychrotrophic strain of Janthinobacterium lividum from a cold Alaskan soil produces prodigiosin. DNA Cell Biol. 29, 533-541.

Smith, S.E., Read, D.J., 2010. Mycorrhizal Symbiosis, third ed. Oxford Elsevier Science Academic Press, London.

Splivallo, R., Deveau, A., Valdez, N., Kirchoff, N., Frey-Klet, P., Karlovsky, P., 2014 Bacteria associated with truffle-fruiting bodies contribute to truffle aroma. Environ. Microbiol. 17 (8), 2647-2660.

Stanier, R.Y., Cohen-Bazire, G., 1957. Microbial Ecology, vol. 56. Camb. Univ. Press.

Tamura, K., Dudley, J., Nei, M., Kumar, S., 2007. MEGA4: molecular evolutionary genetics analysis (MEGA) software version 4.0. Mol. Biol. Evol. 24, 1596-1599.

Trutko, S.M., Dorofeeva, L.V., Evtushenko, L.I., Ostrovskil̆, D.N., Hintz, M., 2005. Isoprenoid pigments in representatives of the family Microbacteriaceae. Mikrobiologiia 74, 335-341.

Tsuchida, T., Koga, R., Horikawa, M., Tsunoda, T., Maoka, T., Matsumoto, S., Simon, J.C., Fukatsu, T., 2010. Symbiotic bacterium modifies aphid body color. Science 330, 1102-1104.

Ventura, M., Canchaya, C., Tauch, A., Chandra, G., Fitzgerald, G.F., Chater, K.F., van Sinderen, D., 2007. Genomics of Actinobacteria: tracing the evolutionary history of an ancient phylum. Microbiol. Mol. Biol. Rev. 71, 495-548.

Zambonelli, A., Iotti, M., 2005. Appennino Modenese, terre da tartufo. Giorgio Mondadori, Milano. 